\title{
Local Capacity Building in the Ecotourism Development
}

\author{
Iwan Nugroho, Rita Hanafie, Purnawan Dwikora Negara, Hefifa Rhesa Yuniar
}

\begin{abstract}
This research aims to study local capacity through regulating the relationships between social, economic and environmental aspects, as well as measuring the sustainability of tourism management. The study was carried out in Ngadas village, Poncokusumo sub-district, Malang regency. The research approach uses surveys to explore qualitative and quantitative data. The method of analysis used path modeling (partly least square, PLS), and a multidimensional scale (MDS). Local capacity has successfully demonstrated the influence of institutions on environmental and economic variables. At the same time, social variables also affect economic variables, and economic variables affect the development of ecotourism. The relationship shows that economic variables become a bridge, which connects the indirect effect of social influence on the development of ecotourism. Measurement of the sustainability index on institutional variables is 41.30, social 36.57, environmental 43.01, and economic 41.76. All variables are categorized as less sustainable. Indicators to support sustainability include infrastructure, improving the village economy, availability of trash bins, protection from landslides, and communication.
\end{abstract}

Keywords: local capacity, social capital, sustainability index, Tengger.

\section{INTRODUCTION}

L ocal capacity becomes an essential component in the sustainability of tourism resource management [1]. Local capacity is an instrument of social aspects that can organize complexity, through regulation, cooperation and empowerment of the parties involved. Local capacity in principle, reflects the condition of social capital, that can be characterized through the establishment of trust, collectivism and authority [2]. Reference [3] identifies the role of social factors in regulating and controlling resource management. Social and environmental factors are interconnected and embedded, which stabilize life in a society or organization. Functional relationships that manifest in socio-cultural life that appreciates environmental values. This explains why

Revised Manuscript Received on January 10, 2020.

* Correspondence Author

Iwan Nugroho, Department of Agribusiness, Faculty of Agriculture, Widyagama University]of Malang. Indonesia. Email: iwanuwg@widyagama.ac.id

Rita Hanafie, Department of Agribusiness, Faculty of Agriculture, Widyagama University of Malang. Indonesia. Email: ritahanafiesrdm@gmail.com

Purnawan Dwikora Negara, Department of Law, Faculty of Law, Widyagama University of Malang. Indonesia.. Email: purnawan_dn@widyagama.ac.id

Hefifa Rhesa Yuniar*, University Library, Widyagama University of Malang. Indonesia.. Email: yuniar.hefifa@gmail.com social aspects of sustainability are always prioritized to underlie the regulation or management of economic and environmental aspects.

The lives of local people have functional values in terms of their social and environmental aspects. The local people need to be developed in potential and empowered to engage in tourism activities [4]. They need to collaborate with other parties, develop innovations to increase the added value of tourism activities. Local policies are designed expertly to empower people, promote tourism, conservation and environmental aesthetics [5].

Ecotourism services have been operated by the local people, and are similar with farming businesses that can provide jobs and livelihoods, and generate income and welfare [6]. However, the participation of local people in ecotourism services still raises the question of whether they carry the vision of conservation or are forced to work into meeting economic needs only. This question is fundamental for the formulation of ecotourism development policy concepts or for building better participation and management of ecotourism at the local level.

The effort to implement the concept of sustainable tourism has always been a challenge. The complexity in tourism activities is very definite, covering social, economic and environmental aspects. These three aspects must be managed optimally and sustainably.

This research aims to study local capacity through regulating the relationships between social, economic and environmental aspects, as well as measuring the sustainability of tourism management.

\section{MATERIALS AND METHODS}

The study used a survey approach involving 41 people who selected randomly. Ngadas Village is located within the Bromo Tengger Semeru National Park (BTSNP) area. The view of the village shows the beauty of panoramic mountains landscape and is often covered a thin mist which makes this village always beautiful, quiet and cool. They carry out the Tengger tradition in various aspects of life [7]. The natural beauty of Bromo and the cultural traditions of Tengger are the main tourist attraction. This village receives tourist visits to the national park area.

The study used a survey approach involving 41 people who selected randomly. Respondents were interviewed based on a questionnaire. Variables observed in this study include the characteristics of respondents, and perceptions related the local capacity, as follow: 


\section{Local Capacity Building in the Ecotourism Development}

a Ecotourism (T), consisting of indicators: (i) increased income, (ii) increased savings, (iii) increased in welfare, (iv) children's education

b Social (S), consisting of indicators: (i) communication, (ii) be tolerant and open, (iii) security in the village, (iv) participation in community, (v) conflict of interest, (vi) hospitality

c Economic (E), consisting of indicators: (i) infrastructure, (ii) increased village economy, (iii) economic cooperation, (iv) participation in economic

d Environment (L), consisting of indicators: (i) environmental conservation, (ii) cleaner environment, (iii) landslides, vulneravility, (iv) availability of trash bins, (v) availability of agricultural plant seeds,

e Institution (K), consisting of indicators: (i) evaluation mechanism, (ii) leadership, (iii) organization role, (iv) transparency, (v) committed to solving problems

Respondent's perceptions of local capacity are expressed in the ordinal scale (Likert). Questions provide five answer choices, including strongly agree (5), agree (4), moderate (3), disagree (2), and strongly disagree (1).

The analytical method uses path modeling (partly least square, PLS), processed using the SmartPLS 3.2.6 software application. The model is constituted hypothetically using the conception and relationship between variables, adopted from [2] and [1].

The second analysis method uses a multidimensional scale (MDS) approach, using R 3.6.0 software application. The MDS method measures the sustainability index of each variable (Table 1) to find sustainable hospitality adjusted for the sustainability category [8]. Data was also tested for validity and reliability through Pearson and Cronbach's Aplha correlation tests using the SPSS 14 application..

\section{RESULTS AND DISCUSSION}

\section{A. Respondent characteristics}

The number of respondents involved in the study was 41 people, with a $20 \%$ proportion of gender. The age of respondents ranged from 25 to 60 years, with an average of 40.6 years. Respondent ages less than 30 years as many as 4 people, between 30 and 50 years is found 31 people, and more than 55 years as many as 6 people (Table 1).

The highest level of education of respondents was junior high school graduates, that was 10 people. The remaining 31 people complete elementary school. This research also revealed respondents' background findings in Ngadas village. They consist of farmers ( 8 people), farmers also homestay owners ( 9 people), farmers who own jeeps (9 people), farmers concurrently as tour operators ( 7 people), and farmers who own shop (8 people).

Ngadas villagers are basically used to serving tourists. Their daily life is living as a farmer. However, on certain days, holidays or weekends they receive tour services by renting a homestay, serving transportation, or guiding tourists. The results of the study [9] show that the profession of farmers and concurrently as tourism actors obtain 1.7 times higher income than farmers alone.

\section{B. Local Capacity}

The conception of local capacity is expressed in relationships or the structural model in Fig. 1. The figure presents the relationship between latent variables and the relationship with the indicators. Latent variables include institution (K), social (S), economic (E), environment (L), and ecotourism (T).

Table- I. Characteristics of the respondent

\begin{tabular}{|l|c|c|}
\hline Variable & Unit & \\
\hline Gender & \% female & 20 \\
\hline Age & years & 40.6 \\
\hline Less than 30 years & people & 4 \\
\hline 30 to 50 years & people & 31 \\
\hline Above 55 years & people & 6 \\
\hline Education level & people & \\
\hline Elementary school & people & 31 \\
\hline Yunior High School & people & 10 \\
\hline Activity group & & \\
\hline Farmer & people & 8 \\
\hline Farmer and Homestay owner & people & 9 \\
\hline Farmer and Jeep rent & people & 9 \\
\hline Farmer and tour operator & people & 7 \\
\hline Farmer and small shop & people & 8 \\
\hline
\end{tabular}

${ }^{a}$ Respondent size 41 people

The model has fulfilled the test to find relevant indicators that explain endogenous variables as presented in Fig. 1. It shows a fairly high loading factor, exceeding the ideal cutting off the value of 0.70 [10]. This means that indicators can explain or influence the character of latent variables so that all latent variables can work in the model.

The next test model is the hypothesis test of the relationship between latent variables as presented in Table 2. The significant relationship between variables ( $p$-value $<0.05$ ) is shown by Social $(\mathrm{S}) \rightarrow$ Economic (E), Institution $(\mathrm{K}) \rightarrow$ Environment $(\mathrm{L})$, and Economic $(\mathrm{E}) \rightarrow$ Ecotourism (T). While the Institution $(\mathrm{K}) \rightarrow$ Economic (E) relationship showed a p-value of 0.193 , or slightly above 0.05 . Also, the relationship between other latent variables is not significant.

The results of this study indicate the role of institution variable and their influence on other variables and their relation to the development of ecotourism. Table 2 states that the institution has a significant effect on the environment ( $p$ $=0.01$ ) with a coefficient of 0.473 . At the same time, social variable is also related to environment variable but is not significant $(\mathrm{p}=0.938)$. The two variables contributed a coefficient of determination of 0.223 to environment variable.

Meanwhile, the institution variable does not significantly influence social variable. The model also displays a coefficient of determination of 0.001 on social variables. This shows that variable of institution also contributes very little to explain social variables, or do not show a significant correlation.

The influence of institution variable on the economy displays a p-value of 0.193 , with a coefficient of 0.171 . This value slightly exceeds $p=0.05$. This relationship can be considered, because of the importance of the role of institutions in economic aspects.

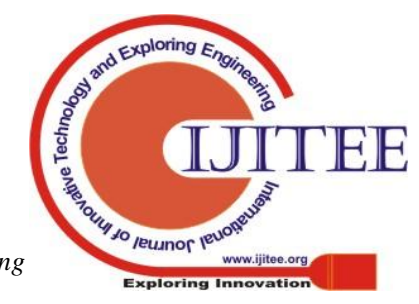


At the same time, social variable also has a significant influence on economic variable $(\mathrm{p}=0.00$; and coefficient 0.709 ). Institution and social variables contribute $\mathrm{R} 2=52.5$ percent to the variety of economic variable. Based on the coefficient figures, the greater contribution is shown by social factors compared to institutions.

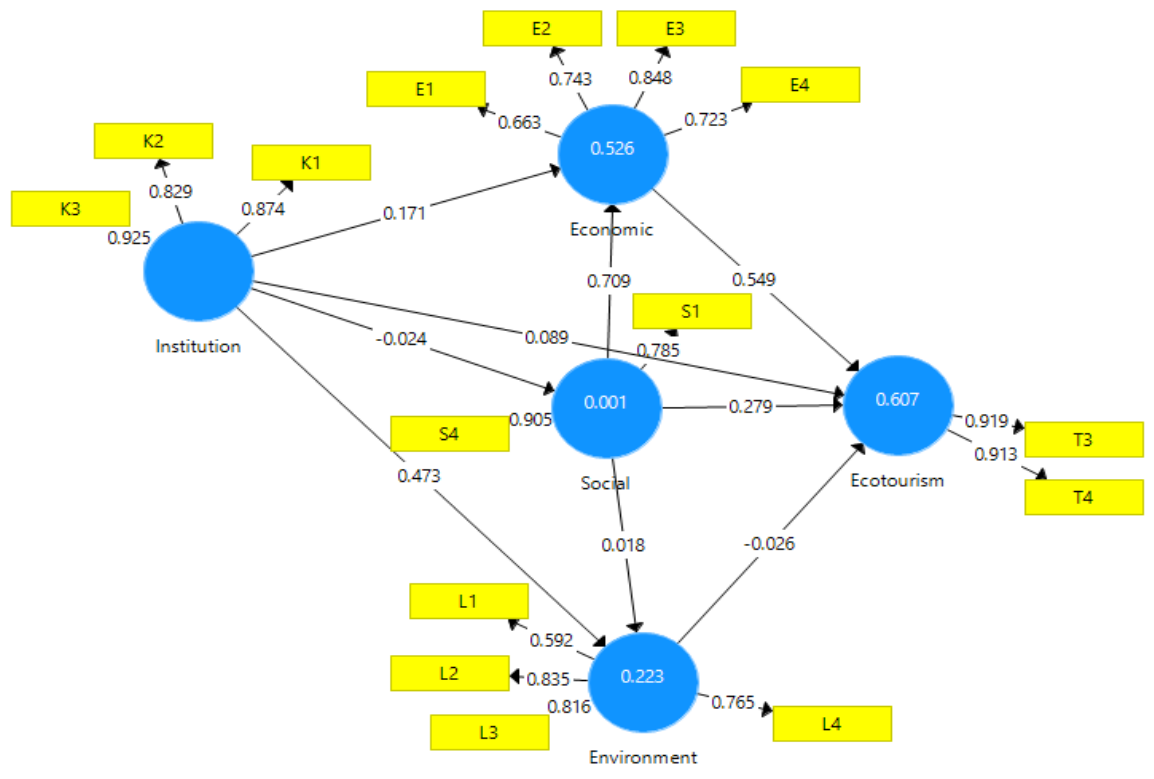

Fig 1. A Model of variable relationship

Table- II. Relationship between latent variables ${ }^{\mathrm{a}}$

\begin{tabular}{|c|c|c|c|}
\hline Latent variable & Path coeficient & t-statistic & p-value \\
\hline Economic $(\mathrm{E}) \rightarrow$ Ecotourism $(\mathrm{T})$ & 0.549 & 2.054 & 0.041 \\
\hline Environment $(\mathrm{L}) \rightarrow$ Ecotourism $(\mathrm{T})$ & -0.026 & 0.170 & 0.865 \\
\hline Institution $(\mathrm{K}) \rightarrow$ Economic $(\mathrm{E})$ & 0.171 & 1.305 & 0.193 \\
\hline Institution $(\mathrm{K}) \rightarrow$ Ecotourism $(\mathrm{T})$ & 0.089 & 0.506 & 0.613 \\
\hline Institution $(\mathrm{K}) \rightarrow$ Environment $(\mathrm{L})$ & 0.473 & 2.572 & 0.010 \\
\hline Social $(\mathrm{S}) \rightarrow$ Economic $(\mathrm{E})$ & 0.709 & 4.902 & 0.000 \\
\hline Social $(\mathrm{S}) \rightarrow$ Ecotourism $(\mathrm{T})$ & 0.279 & 1.045 & 0.296 \\
\hline Social $(\mathrm{S}) \rightarrow$ Environment (L) & 0.018 & 0.078 & 0.938 \\
\hline
\end{tabular}

${ }^{a}$ run by bootstrapping in PLS software. The results show that all latent variables meet the requirements for validity and reliability test. Average Variance Extracted (AVE) and Composite Reliability (CR) exceed the ideal cutting off the value of 0.50 and 0.70 [10]

The significant variable influencing the development of ecotourism is the economic variable $(\mathrm{p}=0.041)$ with a coefficient of 0.549 . The other three variables showed no significant effect, namely social $(\mathrm{p}=0.296)$, institution $(\mathrm{p}=$ $0.613)$ and environment $(\mathrm{p}=0.865)$. The contribution of the three variables is 0.607 or $60.7 \%$ to explain the diversity of tourism development variables.

Furthermore, Fig. 1 explains the significant relationship in Social $(\mathrm{S}) \rightarrow$ Economic $(\mathrm{E})$, and Economic $(\mathrm{E}) \rightarrow$ Ecotourism (T). The relationship shows that economic variables become a bridge, which connects the indirect effect of social influence on the development of ecotourism.

\section{Sustainable Tourism}

The results of measuring the sustainability index of latent variables are presented in Table 3. The Monte Carlo test results show the same figures as the sustainability index. This result shows that the sustainability index meets reliability and stable.

The sustainability index of the variables of economic $(\mathrm{E})$, environment (L), institution (K) and social (S) is categorized

into a less sustainable level (Table 3). These results confirm previous results [11], which found an index below 50 percent, namely ecology is 37.67 percent, economic 41.90 percent, socio-cultural 47.16 percent, and institution is 43.93 percent.

Table- III. Sustainability index of variable or variable

\begin{tabular}{lcc}
\multicolumn{3}{c}{ group } \\
\hline Variable & Value $^{\mathbf{1}}$ & Sustainability Level $^{\mathbf{2}}$ \\
\hline Economic (E) & 41.76 & Less Sustainable \\
Environment (L) & 43.01 & Less Sustainable \\
Institution (K) & 41.30 & Less Sustainable \\
Social (S) & 36.57 & Less Sustainable \\
\hline Reliability test using the Monte Carlo method on each variable shows a \\
difference of no more than 0.01 units \\
${ }^{2} 0$ - 24.99: Not Sustainable; 25 - 49.99: Less Sustainable; 50 - 74.99: Fairly \\
Sustainable and 75 - 100.00: Sustainable
\end{tabular}

Furthermore, Table 3 shows in more detail that the social variable shows the lowest number, which is 36.57 . This is in line with [3], which identifies the role of social

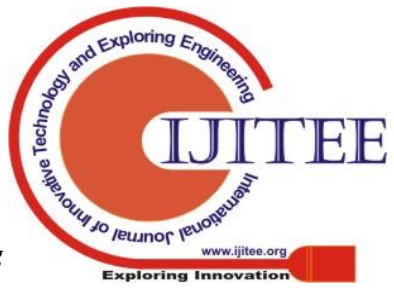




\section{Local Capacity Building in the Ecotourism Development}

factors in managing and controlling resource management.

This explains why social aspects of sustainability are always prioritized to underlie the regulation or management of economic and environmental aspects.

The MDS approach also needs to consider the value of the leverage of each indicator (Fig. 2). Test the validity and reliability of the indicators carried out to ensure the variable instruments can work valid and robust. The Pearson correlation results show that indicators $\mathrm{S} 2, \mathrm{~S} 3, \mathrm{~L} 5, \mathrm{~K} 4$, and K5 are invalid so they must be excluded from the leverage analysis. Meanwhile, the result of Cronbach's Alpha 0.722 indicate a valid variable instrument.

To complete the sustainability index, leverage measurement can further explain which indicators as levers for the benefit of management. The focus is to scrutinize at indicators on the variables that have low sustainability index values.

Low leverage values include infrastructure (E1), availability of trash bins (L4), protection from landslides (L3), improvement of the village economy (E2), and communication (S1). The low leverage is very relevant to the conditions and environment of the Ngadas village.

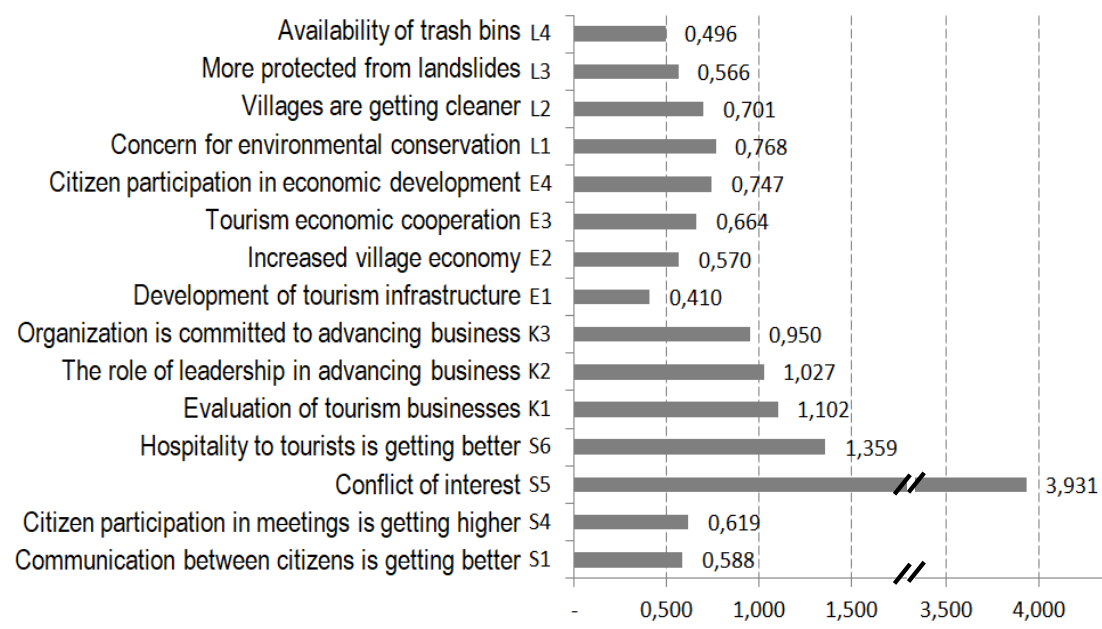

Fig. 2. Leverage indicator of each variable

In economic aspect, infrastructure has become significant obstacles, especially roads leading to tourist sites in the village, even though the main road to Mount Bromo is adequate. The infrastructure factor is not only to maintain sustainability but also to increase rural tourism competitiveness. Improvement of the village economy can strengthen sustainability because many villagers still depend on agriculture for their livelihoods. Nevado-Peña et all. state that the economic aspect is a significant component of sustainability and at the same time supported by social and environmental aspects [12].

In environmental aspect, trash bins are available, but the amount is not enough. Most villagers also do not use the trash. Garbage is more often burned or used for compost. Landslide potential is very high due to steep topography, especially on agricultural land without land cover. The position of the Ngadas village is within BTSNP; thus villagers must follow the national park conservation guidelines to manage cropland [4]. The environmental conservation approach is the primary reference for the management framework. Coordination of all parties will help promote sustainable tourism [5]. Reference [13] further shows that environmental factors have the most influence on the use of land resources in the national park area compared to social and economic factors.

In the social aspect, communication between local people needs to be developed continuously to build harmony and strengthen tourism management activities. The study [14] identifies the impact of coastal tourism on social aspects, rather than the environment and economy. Musavengane states that is communication as social capital to build cooperation and management of natural resources [15]. Communication is also a way to meet the expectations of all parties, including tourism management goals, and to instill a vision of conservation of tourist destinations [16].

\section{CONCLUSION}

Social capacities have successfully demonstrated institution influences on environment and economic variables. The relationship shows that economic variable becomes a bridge, which connects the indirect effect of social influence on the development of ecotourism.

Measurement of the sustainability index on the institution variable is 41.30, social 36.57, environmental 43.01, and economic 41.76. All variables are categorized as less sustainable. Furthermore, the indicators that to support sustainability in the Ngadas village area, namely infrastructure, improvement of the village economy, availability of trash bins, protection from landslides, and communication.

\section{ACKNOWLEDGMENT}

This research was funded by research grant scheme from the Directorate of Research and Community Service of the Ministry of Research Technology and Higher Education, Government of Indonesia, fiscal year 2019. 


\section{REFERENCES}

1 M. Schwaninger, "Systemic design for sustainability," Sustain. Sci., vol. 13, no. 5, pp. 1225-1234, Sep. 2018

2 M. Yolles, "Sustainability development: part 1 - from the cybernetic of cybernetics to the cybernetics of development," Int. J. Mark. Bus. Syst., vol. 3, no. 3, pp. 238-256, 2018.

3 M. Yolles, "Sustainability development: part 2 - exploring the dimensions of sustainability development," Int. J. Mark. Bus. Syst., vol. 3, no. 3, pp. 257-275, 2018.

4 J. Solár, M. Janiga, and K. Markuljaková, "The socioeconomic and environmental effects of sustainable development in the Eastern Carpathians, and protecting its environment," Polish J. Environ. Stud., vol. 25, no. 1, pp. 291-300, 2016.

5 J. C. C. Lopez and K. Bhaktikul, "Sustainable environment and tourism industry: An institutional policy analysis of northeastern Thailand," Polish J. Environ. Stud., vol. 27, no. 1, pp. 31-37, 2018.

6 I. Nugroho, F. H. Pramukanto, P. D. Negara, W. Purnomowati, and W. Wulandari, "Promoting the Rural Development through the Ecotourism Activities in Indonesia," Am. J. Tour. Manag., vol. 5, no. 1, pp. 9-18, 2016.

7 P. Purnomo, A. In Oktaviani, and I. Nugroho, "The Sacred Site: The Conservation Based on The Local People in Tengger Community And Its Potential as Ecotourism Activities," J. Socioecon. Dev., vol. 1, no. 1, pp. 7-15, 2018.

8 T. J. Pitcher and D. Preikshot, "RAPFISH: A rapid appraisal technique to evaluate the sustainability status of fisheries," Fish. Res., vol. 49, no. 3, pp. 255-270, 2001.

9 W. Purnomowati, I. Nugroho, and P. D. Negara, "Entrepreneurship Ability On Ecotourism Services Of Local People In Taman Nasional Bromo Tengger Semeru, Malang Regency, East Java, Indonesia .," in 11th International Entrepreneurship Forum (11th IEF) Conference Entrepreneurship and Sustainability: From Lifestyles to Innovative Enterprises in Creative and Sustainable Environments, 2012, pp. 458-473.

10 I. Ghozali, Aplikasi analisis multivariate dengan program SPSS Semarang: Badan Penerbit Universitas Diponegoro, 2006.

11 A. B. Santosa, D. Marsono, S. Susanto, and R. Sadono, "Sustainable national park management using multidimensional scaling: Study of Palung Mountain National Park (PMNP) in West Kalimantan," Adv. Environ. Biol., vol. 8, no. 5, pp. 1873-1880, 2014.

12 D. Nevado-Peña, V. R. López-Ruiz, and J. L. Alfaro-Navarro, “The effects of environmental and social dimensions of sustainability in response to the economic crisis of European cities," Sustain., vol. 7, no. 7, pp. 8255-8269, 2015.

13 B. G. Prasasti, S. Basuni, and T. Sunarminto, "Determinant Factor Analysis of Sustainability And Land Use Strategy In Lokapurna Mount Halimun Salak National Park," Media Konserv. , vol. 21, no. 3, pp. 286-294, 2016.

14 N. P. Dwipayana, E. N. Kencana, and N. K. T. Tastrawati, "Memodelkan Dampak dan Keberlanjutan Pariwisata Pesisir di Kabupaten Badung Provinsi Bali,” E-Jurnal Mat., vol. 7, no. 2, pp. 111-121, May 2018.

15 R. Musavengane, "Using the systemic-resilience thinking approach to enhance participatory collaborative management of natural resources in tribal communities: Toward inclusive land reform-led outdoor tourism," J Outdoor Recreat. Tour., vol. 25, pp. 45-56, 2019.

16 M. M. Solís-Radilla, L. Hernández-Lobato, L. J. Callarisa-Fiol, and H. T. Pastor-Durán, "The Importance of Sustainability in the Loyalty to a Tourist Destination through the Management of Expectations and Experiences," Sustainability, vol. 11, no. 15, p. 4132, Jul. 2019.

\section{AUTHORS PROFILE}

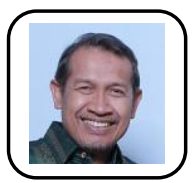

Dr. Iwan Nugroho is a Professor at the Department of Agribusiness, Faculty of Agriculture, Widyagama University of Malang. He completed his PhD in 2002, from Bogor Agriculture University, Indonesia, by submitting a dissertation on urban water management. $\mathrm{He}$ has experienced teaching and researching for more than twenty-five years, in the areas of regional development, natural resource management and the environment, and ecotourism development. He has written journal articles, conference articles and books in his scientific field. He also conducts supervision for students who complete MSc and $\mathrm{PhD}$ programs. He is also a member of the editorial board of the Journal of Indonesian Tourism and Development Studies; and the editor in chief of the Journal of Socioeconomics and Development. He is also a reviewer of various reputable conferences or journals. Publication experience and as a peer review can be seen at https://orcid.org/0000-0002-2494-0983

https://publons.com/researcher/1686335/iwan-nugroho/

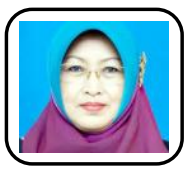

Dr. Rita Hanafie is currently working as an Assistant Professor in the Department of Agribusiness, Faculty of Agriculture, Widyagama University of Malang. She completed PhD study in 2007, from Brawijaya University, Indonesia, by completing a dissertation on agribusiness management. She has taught students and worked on research at her campus for more than twenty-five years, in the fields of agribusiness management, rural community nutrition, food security, and agricultural economics. She has written journal articles, conference articles and books in her scientific field. She also worked on a research project on the food and nutritional needs of rural households in collaboration with the provincial government of East Java. She is also a member of the editorial board of the Journal of Socioeconomics and Development.

Dr. Purnawan Dwikora Negara is an Assistant Professor in the Law Department, Faculty of Law, Widyagama University of

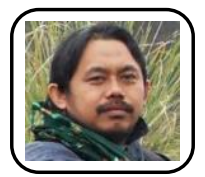
Malang. He completed his $\mathrm{PhD}$ in 2014 from Diponegoro University, Semarang, Indonesia, working on a dissertation on local wisdom as a source of law. He has taught students and worked on research at his campus for more than twenty-five years, in the fields of environmental law, customary law, community development, and sustainable tourism. He has written articles for journals and conferences. $\mathrm{He}$ also works in an environmental NGO (WALHI Indonesia) as the East Java regional coordinator. He is intensively involved in training and counseling for people affected by environmental damage, and advocating for them to obtain social rights. He is also a member of the editorial board of the Journal of Socioeconomics and Development.

Ms. Hefifa Rhesa Yuniar is a Research Assistant, who also works as a university librarian at Widyagama University of Malang.

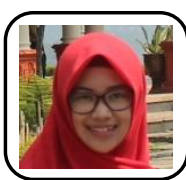
She completed his Bachelor in 2015, from Airlangga University, Surabaya, Indonesia. She has experience as a traveler and also a writer who explores the subject of nature tourism and sustainable tourism. She was actively involved in attending the seminar and presented the paper in a conference on sustainable tourism. She is also an editorial assistance from the Journal of Socioeconomics and Development. 